\title{
(On)zekerheden bij het financieren van het product-als-dienstmodel $^{*}$
}

\author{
C.H.A. van Oostrum
}

\section{$1 \quad$ Inleiding}

Ondernemingen financieren dikwijls een deel van hun ondernemingsactiviteiten met vreemd vermogen. Ter securering van het aangetrokken vreemde vermogen worden zekerheden geboden aan de externe financier, meestal een bank. De bank heeft hierbij een voorkeur voor zakelijke zekerheidsrechten. Dit komt vanwege de aan deze rechten verbonden voorrangspositie bij verhaal. De bank kan op grond van deze zekerheidsrechten als separatist optreden in het faillissement van de schuldenaar. ${ }^{1}$

Ook ondernemingen met een circulair verdienmodel ${ }^{2}$ wenden zich dikwijls tot de bank voor krediet. Daarnaast proberen deze ondernemingen via leaseconstructies (werk)kapitaal te verkrijgen. Verder doen deze ondernemingen soms een beroep op alternatieve vormen van financiering zoals crowdfunding. Kortom, circulaire ondernemingen kunnen uit verschillende bronnen externe financiering aantrekken. Niettemin ervaren zij moeilijkheden om te voorzien in hun behoefte aan vreemd vermogen. Dit komt niet zelden door hun innovatieve verdienmodellen die voor kredietverstrekkers onzekerheden bevatten. ${ }^{3}$

Een van deze verdienmodellen is het product-als-dienstmodel. Dit verdienmodel heeft niet tot doel om een product te verkopen, maar om een productprestatie te leveren. De producent/verhuurder van lampen levert in dit model geen lampen, maar lumen ${ }^{4}$ en de producent/verhuurder van bedden levert geen bed, maar een slaapdienst. ${ }^{5}$ Het gebruik van het product wordt door de producent/verhuurder verschaft aan de klant/huurder gedurende de looptijd van de overeengekomen

* De auteur dankt Martijn Rongen voor zijn commentaar op eerdere versies van dit artikel.

1 Art. 3:227 jo. art. 3:278 lid 1 BW jo. art. 57 lid 1 Fw.

2 Een circulair verdienmodel is een verdienmodel dat in lijn is met de uitgangspunten van de circulaire economie, zie par. 2.

3 ING Economics Department, Rethinking finance in a circular economy, 2015, p. 35, 39; Nederlandse Vereniging van Leasemaatschappijen, Equipment Leasebranche heeft sleutelrol in de transitie naar de Circulaire Economie, 2016, www.abnamrolease.com/media/1639/20161212leasebranche-en-circulaire-economie-def.pdf (geraadpleegd op 24 januari 2020), par. 4.3; Working Group finance, Money makes the world go round (and will it help to make the economy circular as well?), 2016, www.ellenmacarthurfoundation.org/assets/downloads/ce100/FinanCE.pdf (geraadpleegd op 24 januari 2020), p. 101; A.M Schmidt, Diensten in de circulaire economie en enkele privaatrechtelijke belemmeringen, Milieu en Recht 2017/120, par. 3. Planbureau voor de Leefomgeving, Circulaire economie in kaart, Den Haag: Planbureau voor de Leefomgeving 2019, p. 43-44.

4 Philips Circular Lighting, www.lighting.philips.nl/systemen/circular-lighting (geraadpleegd op 24 januari 2020).

5 Bedgarant, www.bedgarant.nl (geraadpleegd op 24 januari 2020). 
gebruiksperiode. Na afloop van deze periode wordt het product geretourneerd aan de producent/verhuurder. Als uitgangspunt geldt dat de eigendom van het product bij de producent/verhuurder blijft. Hierdoor wordt de producent/verhuurder aangespoord om het product zo duurzaam mogelijk te ontwerpen, het product zo goed mogelijk te onderhouden en grondstoffen uit het product te hergebruiken. Het valt hierbij op dat het product-als-dienstmodel wordt toegepast op een steeds grotere variëteit aan producten: van witgoed $^{6}$ tot spijkerbroeken. ${ }^{7}$

Voor de bank kan het lastig zijn om een goede risico-inschatting te maken bij een kredietaanvraag van een circulaire onderneming met een product-als-dienstmodel. De bank gebruikt voor haar risico-inschatting normaliter criteria die gelden bij de lineaire economie. De bank beoordeelt de krediet vragende onderneming gewoonlijk op haar kasstroom, solvabiliteit, track record en de omvang en de kwaliteit van de geboden zekerheden. Ondernemingen met een product-als-dienstmodel (en andere circulaire verdienmodellen) wijken dikwijls af van de gebruikelijke - en in een lineaire economie gewenste - waarden die banken zoeken in de financiële kengetallen. De achtergrond hiervan wordt duidelijk bij het vergelijken van een regulier handelsmodel met een product-als-dienstmodel.

$\mathrm{Bij}$ een handelsmodel levert een transactie direct inkomsten op. Bij een productals-dienstmodel levert het afsluiten van een huur-/leaseovereenkomst inkomsten op die zijn uitgesmeerd over een langere periode. Dit vraagt om een andere waardering van de kasstroom. Ook de solvabiliteit die hoort bij het product-als-dienstmodel is anders vergeleken met de solvabiliteit van een handelsmodel. Dikwijls moet er bij het product-als-dienstmodel relatief veel werkkapitaal worden ingezet om de klant het gebruik van het product te kunnen verschaffen en de dienstverlening te kunnen organiseren. Dit leidt tot balansverlenging met als gevolg een minder gunstige solvabiliteit. Hierbij is het track record van circulaire ondernemingen met enige regelmaat beperkt. ${ }^{8}$

Uiteraard kan de bank zijn risico-inschattingsmodel aanpassen aan de verdienmodellen van circulaire ondernemingen. Veelal zal dit betekenen dat de bank de 'circulaire ondernemingsplannen' nog beter moet doorgronden dan gebruikelijk. Dit is geen sinecure, al was het maar omdat het niet altijd duidelijk is wat onder circulair ondernemen wordt verstaan. ${ }^{9}$ De bank zal daarom geruststelling proberen te vinden bij de geboden zekerheden. Dit is niet alleen belangrijk voor de bank, maar ook voor de krediet zoekende onderneming, die doorgaans zonder zekerheden geen vreemd vermogen kan aantrekken.

Het is daarom lastig dat deze circulaire ondernemingen en ook de bank problemen ervaren bij de zekerheidsstelling. Deze problemen komen voort uit het gegeven dat circulaire ondernemingen met een product-als-dienstmodel dit model toepassen op producten die een lagere waarde vertegenwoordigen (bijvoorbeeld op kleding of fietsen) of op producten die vatbaar kunnen zijn voor natrekking

6 Bosch, www.bluemovement.nl (geraadpleegd op 24 januari 2020).

7 MUD Jeans, www.mudjeans.eu/lease-a-jeans (geraadpleegd op 24 januari 2020).

8 Working Group finance 2016, p. 86-87.

9 ABN AMRO, ING and Rabobank, Circular Economy Finance Guidelines, 2018, www.abnamro.com/nl/images/Documents/040_Duurzaamheid/Publications/ABN_AMRO_ Circular_Economy_Finance_Guidelines_2018.pdf (geraadpleegd op 24 januari 2020), p. 2. 
(zoals zonnepanelen of gevelbekleding). Hierin verschillen circulaire ondernemingen met een product-als-dienstmodel van traditionele ondernemingen met een product-als-dienstmodel zoals autoleasemaatschappijen. Het is daarom interessant om indachtig het secureren van ondernemingskrediet te bekijken welke problemen partijen tegenkomen, in welke mate het vigerend recht voor oplossingen kan zorgen en wat volgens de literatuur ter zake wenselijk recht is. Dit artikel richt zich primair op de zekerheidsverlening bij bankfinanciering en bij lease. Omwille van de leesbaarheid wordt in gevallen waar het zowel om een bank als leasemaatschappij kan gaan, gesproken van een bank. Waar alleen wordt gedoeld op een leasemaatschappij, wordt deze term gehanteerd.

In paragraaf 2 wordt een beknopte achtergrond gegeven van de circulaire economie in het algemeen en het product-als-dienstmodel in het bijzonder. Vervolgens wordt in paragraaf 3 de rol die (zakelijke) zekerheden spelen bij het verlenen en verkrijgen van vreemd vermogen uiteengezet. In paragraaf 4 wordt natrekking besproken in relatie tot het product-als-dienstmodel, zakelijke zekerheden en ICT-toepassingen. Dit artikel wordt in paragraaf 5 afgesloten met slotbevindingen.

\section{Circulaire economie en het product-als-dienstmodel}

Onder circulaire economie wordt doorgaans verstaan:

'een economisch en industrieel systeem dat de herbruikbaarheid van producten en grondstoffen en het herstellend vermogen van natuurlijke hulpbronnen als uitgangspunt neemt, waardevernietiging in het totale systeem minimaliseert en waardecreatie in iedere schakel van het systeem nastreeft. ${ }^{10}$

Met deze uitgangspunten is de circulaire economie de tegenhanger van de lineaire economie.

Bij de lineaire economie worden grondstoffen eenmalig gebruikt om mee te produceren. Aan het einde van de levenscyclus van een product worden de grondstoffen waaruit het product bestaat, gezien als afval. De lineaire economie is een takemake-waste model. In de circulaire economie wordt 'afval' niet gezien als een eindstadium van grondstoffen, maar als een beginstadium. Afval is een bron van grondstoffen die kunnen worden hergebruikt. Het doel is om grondstoffen (in welke vorm deze ook zijn verwerkt) in een kringloop te houden: van grondstof naar afval naar grondstof. De circulaire economie beoogt om kringlopen te sluiten. ${ }^{11}$

Om kringlopen te sluiten is het dikwijls noodzakelijk dat ketenpartners intensief samenwerken, bijvoorbeeld als het afval van onderneming één wordt gebruikt als grondstof door onderneming twee. Langetermijnafspraken over het verdelen van

10 T. Bastein e.a., Kansen voor de circulaire economie in Nederland, TNO-rapport 2013/R10864, p. 7.

11 Bastein e.a. 2013, p. 10 e.v. Zie ook Ellen MacArthur Foundation, Towards a Circular Economy. Economic and business rationale for an accelerated transition, 2013, p. 22 e.v. 
kosten, opbrengsten en risico's zijn in de regel onvermijdelijk. Dit is ook belangrijk voor de bank. Bij een financieringsaanvraag voor een circulaire propositie kan de kwaliteit van de (keten)overeenkomsten dan ook van doorslaggevend belang zijn.

Er bestaan diverse strategieën die invulling geven aan circulariteit: van energieterugwinning uit afval tot het voorkomen van grondstofgebruik. Om deze strategieën te kunnen beoordelen op de mate waarin zij beantwoorden aan de uitgangspunten van de circulaire economie, kan gebruik worden gemaakt van verschillende modellen. De zogenoemde 10R-ladder van Cramer voor de abiotische kringloop is hiervan een bekend voorbeeld. Dit model rangschikt aan de hand van tien niveaus de circulaire impact van een strategie. ${ }^{12}$

Op de bovenste treden van de 10R-ladder staan strategieën die het meest beantwoorden aan de uitgangspunten van de circulaire economie. Deze strategieën zijn erop gericht om producten zo te ontwerpen dat het grondstofgebruik tot een absoluut minimum wordt beperkt (Refuse, Reduce en Renew). Hierna volgen strategieën die tot doel hebben om de levensduur van een product te verlengen (Reuse, Repair, Refurbish, Remanufacture en Re-purpose). Op de onderste treden van de ladder staan strategieën die zich alleen richten op het hergebruik van grondstoffen uit producten (Recycle en Recover). De voornoemde strategieën worden gebruikt in circulaire verdienmodellen zoals deelplatforms, refurbishment en product-als-dienst. ${ }^{13}$

12 J. Kirchherr, D. Reike \& M. Hekkert, Conceptualizing the circular economy: An analysis of 114 definitions, Resources, Conservation and Recycling 2017, p. 221-232.

13 Zie figuur 1. J. Potting e.a., Circulaire economie: innovatie meten in de keten, Den Haag/Utrecht: Planbureau voor de Leefomgeving en Universiteit Utrecht 2016, p. 15. 
Figuur 1 De 10R-ladder ${ }^{14}$

\begin{tabular}{|c|c|c|}
\hline \multirow{11}{*}{ 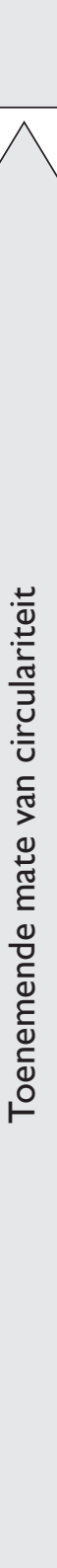 } & \multicolumn{2}{|c|}{$\begin{array}{c}\text { Waardering van circulariteitsstrategieën } \\
\text { volgens de IOR-ladder }\end{array}$} \\
\hline & Pros & $\begin{array}{l}\text { I. Refuse: het voorkomen van } \\
\text { grondstofgebruik. }\end{array}$ \\
\hline & $\begin{array}{l}\text { gericht op zo } \\
\text { min mogelijk }\end{array}$ & $\begin{array}{l}\text { 2. Reduce: het verminderen van } \\
\text { grondstofgebruik. }\end{array}$ \\
\hline & gebruik & $\begin{array}{l}\text { 3. Renew: het herontwerpen van } \\
\text { een product indachtig circulariteit. }\end{array}$ \\
\hline & \multirow{5}{*}{$\begin{array}{l}\text { Verlengen } \\
\text { van de } \\
\text { levensduur } \\
\text { van het } \\
\text { product }\end{array}$} & $\begin{array}{l}\text { 4. Re-use: het hergebruiken van } \\
\text { een product (tweedehands). }\end{array}$ \\
\hline & & $\begin{array}{l}\text { 5. Repair: het onderhouden en } \\
\text { repareren van een product. }\end{array}$ \\
\hline & & $\begin{array}{l}\text { 6. Refurbish: het moderniseren en } \\
\text { opknappen van een product. }\end{array}$ \\
\hline & & $\begin{array}{l}\text { 7. Remanufacture: van een } \\
\text { afgedankt product een nieuw } \\
\text { product maken. }\end{array}$ \\
\hline & & $\begin{array}{l}\text { 8. Repurpose: een nieuwe functie } \\
\text { geven aan een afgedankt product. }\end{array}$ \\
\hline & \multirow{2}{*}{$\begin{array}{l}\text { Hergebruiken } \\
\text { van grond- } \\
\text { stoffen uit } \\
\text { het product }\end{array}$} & $\begin{array}{l}\text { 9. Recycle: het hergebruiken van } \\
\text { de grondstoffen in een product. }\end{array}$ \\
\hline & & $\begin{array}{l}\text { 10. Recover: energieterugwinning } \\
\text { uit afval. }\end{array}$ \\
\hline
\end{tabular}

14 Geïnspireerd op: J. Cramer, Strategische Verkenning. Op weg naar Cirkelregio Utrecht, 2015, p. 12. 


\subsection{Het product-als-dienstmodel}

Het product-als-dienstmodel is gericht op het leveren van een productprestatie. Hiertoe maken de producent/verhuurder en de klant/huurder afspraken. Het uitgangspunt is hierbij dat de eigendom van het te verhuren product bij de producent/verhuurder blijft. Dit stimuleert de producent/verhuurder om het product conform de circulaire uitgangspunten zo veel mogelijk waarde te laten behouden. Afspraken tussen de producent/verhuurder en de klant/huurder worden dikwijls vormgegeven in een duurovereenkomst zoals een huur-/ leaseovereenkomst. ${ }^{15}$ De vorm van de overeenkomst hangt mede af van de wijze waarop de producent/verhuurder zijn investering financiert. De producent/verhuurder kan met de bank overeenkomen dat hij zowel juridisch als economisch eigenaar wordt van het product of dat alleen het economische eigendom hem toekomt. Een voorbeeld van een mogelijk toepasselijke leaseconstructie is de vendor lease. De bank financiert de investering van de producent/verhuurder die op zijn beurt het product aanbiedt aan de klant/huurder. Bij de vendor lease-constructie ontstaat een driepartijenverhouding tussen de producent/verhuurder, de bank en de klant/huurder. Doorgaans biedt deze leaseconstructie alleen uitkomst als de betreffende zaak identificeerbaar is en een goed te voorspellen waardepatroon heeft. ${ }^{16}$

Op de keper beschouwd is het product-als-dienstmodel geen nieuw fenomeen. Immers, leaseconstructies worden al sinds jaar en dag gebruikt en de leasemarkt is met miljarden euro's aan uitstaande leasecontracten bepaald geen klein bier. ${ }^{17}$ Een voorbeeld van een dergelijke leasemarkt is de autoleasemarkt. Het vernieuwende aspect van het product-als-dienstmodel in de circulaire economie ten opzichte van de traditionele leasemarkt is, zoals reeds in de inleiding vermeld, dat dit model op een veel grotere variëteit aan producten wordt toegepast. Deze ruime toepassing van het model brengt (juridische) onzekerheden met zich.

Bijvoorbeeld ingeval de klant/huurder zijn betalingsverplichtingen niet nakomt en de verhuurde producten een lage waarde vertegenwoordigen zoals bij kledingstukken. De producent/verhuurder loopt inkomsten mis terwijl het product in het bezit is van de klant/huurder. De producent/verhuurder zou de gang naar de rechter kunnen maken om nakoming te vorderen. Echter, dit is economisch gezien alleen rationeel zolang de kosten van een juridische procedure de opbrengsten ervan niet ontstijgen. Deze situatie is niet alleen onwenselijk voor de producent/verhuurder, maar is ook in strijd met de uitgangspunten van de circulaire economie. Het product komt namelijk niet terug in handen van de producent/verhuurder die er primair zorg voor hoort te dragen. Ook voor de bank is deze situatie ongewenst: de inkomsten uit contract zijn niet gegarandeerd. Dit 
gegeven kan bij de bank leiden tot terughoudendheid om dergelijke circulaire proposities te financieren. ${ }^{18}$

\section{Zekerheden en ondernemingsfinanciering}

Bij het verstrekken van financiering heeft de bank rekening te houden met (1) het tegenpartijrisico en (2) het aanhouden van kapitaal voor de door haar verstrekte financiering. In dit kader zorgen zekerheden voor het afdekken van het tegenpartijrisico en dragen ertoe bij dat de bank solvabiliteitsvrijval kan bewerkstelligen. De bank hoeft namelijk minder kapitaal aan te houden als de door haar verstrekte financiering gedekt wordt door zekerheden. ${ }^{19}$

De kosten van de financiering hangen samen met het risico dat de bank loopt bij het verstrekken ervan. Hoe groter het risico, hoe hoger de kosten van de financiering. Omdat zekerheden het financieringsrisico verkleinen, kunnen zekerheden de kosten van de financiering voor de krediet vragende onderneming verlagen. Hierbij moeten de verstrekte zekerheidsrechten rechtens correct zijn gevestigd en de in zekerheid gegeven goederen betrekkelijk eenvoudig zijn uit te winnen. ${ }^{20}$

De financiering wordt normaliter gesecureerd met zakelijke zekerheden. Bijvoorbeeld door vorderingen of voorraden te verpanden of door onroerend goed te verhypothekeren. De bank hecht belang aan zakelijke zekerheden omdat dit type zekerheid de bank in staat stelt om als separatist op te treden in het faillissement van de schuldenaar. De financiering (of een deel daarvan) kan (aanvullend) ook worden gesecureerd met persoonlijke zekerheden. Bij concernfinanciering is dit zelfs gebruikelijk. Het is in Nederland staande praktijk dat de groepsmaatschappijen zich jegens de bank hoofdelijk aansprakelijk verklaren voor het concernkrediet. Een ander voorbeeld betreft borgstelling door de directeur-grootaandeelhouder voor de financiering van de onderneming. Persoonlijke zekerheden leveren de bank geen voorrangspositie op, maar een extra verhaalsobject in de vorm van het vermogen van een derde. ${ }^{21}$

Vaak kan een startende onderneming met een product-als-dienstmodel weinig meer zekerheid bieden dan (1) een pandrecht op haar (toekomstige) vorderingen en, mits het product zich hiervoor leent en eigendom van de producent/verhuurder is, (2) een zekerheidsrecht op het te verhuren product. Afhankelijk van de situatie kan een pandrecht of een hypotheekrecht worden gevestigd. Verder komt het bij leaseconstructies voor dat het juridisch eigendom van het product (als zekerheid) in handen van de leasemaatschappij blijft. Zowel bij punt (1) als bij punt (2) kan de bank (of leasemaatschappij) risico-inschattingsproblemen ervaren.

18 Schmidt 2017, par. 5.1.

19 Art. 92 lid 3a en 197-199 CRR.

20 F.E.J. Beekhoven van den Boezem \& R. van den Bosch, Zekere zekerheid, Maandblad voor Vermogensrecht 2015, nr. 07/08, p. 200-207, p. 200.

21 C.H.A. van Oostrum, Regres bij concernfinanciering (Serie Van der Heijden Instituut nr. 156), Deventer: Wolters Kluwer 2019, p. 115-117. 
Ter zake van punt 1 zal de bank de kredietwaardigheid van de (toekomstige) schuldenaren van de onderneming moeten beoordelen. De kredietwaardigheid van deze partijen bepaalt in zekere mate de kwaliteit van het pandrecht op de vorderingen. Immers, bij een lage kredietwaardigheid van deze partijen bestaat er meer risico dat gedurende de looptijd van de overeenkomst de betalingen stokken. Vanzelfsprekend biedt een pandrecht gevestigd op vorderingen op betalingsonmachtige debiteuren niet de gewenste zekerheid. Verder is de bank ook weinig geholpen met het aan haar bij voorbaat verpanden of cederen van toekomstige (huur)vorderingen. In verband met het in art. 35 lid 2 Fw bepaalde houdt een dergelijke verpanding of cessie geen stand in het faillissement van de producent/verhuurder. Mede hierom is de zekerheid over het te verhuren product (en de executiewaarde die het vertegenwoordigt) belangrijk voor de bank.

Bij punt 2, het verkrijgen van een zekerheidsrecht op het te verhuren product, moet de bank inzicht hebben in het waardeverloop van het product en de invloed van de gebruikers hierop. Uit onderzoek blijkt dat gebruikers minder zorgvuldig omgaan met gehuurde spullen dan met zaken die zij in eigendom hebben. Verder moet de bank bedacht zijn op de mogelijkheid dat de levensduur van een product (en de waarde ervan) bepaald wordt door modegrillen en status en in mindere mate door de technische levensduur. Dit gegeven is ook van belang omdat het product-als-dienstmodel gewoonlijk rendabel is wanneer het product wordt gebruikt voor de volle technische levensduur. Veranderende mode- en statusbeleving kunnen daarom een negatief effect hebben op de levensvatbaarheid van een product-als-dienstpropositie. $^{22}$

De bank moet eveneens bedacht zijn op het risico van natrekking van het verhuurde product. Natrekking heeft invloed op de zekerhedenpositie van zowel de producent/verhuurder als van de bank. Natrekking leidt ertoe dat de producent/ verhuurder de eigendom verliest van het verhuurde product. De bank verliest door natrekking het op het product gevestigde zekerheidsrecht. Ook bij leaseconstructies waarbij de leasemaatschappij de juridisch eigendom op het product heeft, zorgt natrekking ervoor dat de leasemaatschappij haar zekerheid (de eigendom van het product) kwijtraakt.

Toch is natrekking van het product niet acuut problematisch. Het gaat er tenslotte om dat de producent/verhuurder huurinkomsten ontvangt en dat hij aan het einde van de huurperiode het product terugkrijgt. Dit laatste kan hij van de huurder verlangen krachtens art. 7:224 lid 1 BW. Mocht de huurder niet overgaan tot het retourneren van het gehuurde, dan kan de producent/verhuurder een vordering instellen op grond van wanprestatie of op grond van ongerechtvaardigde verrijking.

Als de huurder failliet gaat, ligt de situatie voor de producent/verhuurder mogelijk anders. Hoewel bestaande duurovereenkomsten ook in faillissement doorlopen, kan de curator de huurovereenkomst betrekkelijk eenvoudig opzeggen. Daarnaast is vanaf de dag van faillietverklaring de huurprijs boedelschuld. ${ }^{23}$ Verder zullen eventuele vorderingen van de producent/verhuurder moeten concurre- 
ren met vorderingen van schuldeisers met een zakelijk zekerheidsrecht. Dit is een weinig hoopvol scenario voor de producent/verhuurder.

(Dreigende) natrekking van het product kan ook tot gevolg hebben dat beoogde zekerheidsrechten niet kunnen worden gevestigd. De producent/verhuurder kan bijvoorbeeld geen zekerheidsrecht vestigen op een circulaire gevel die door natrekking eigendom wordt van de klant/huurder. Dit komt omdat natrekking ertoe leidt dat de oorspronkelijke eigenaar van het product beschikkingsonbevoegd wordt om op het product een zekerheidsrecht te vestigen ten behoeve van de bank. Aanvullende juridische handelingen zijn nodig om de beschikkingsonbevoegdheid te voorkomen. ${ }^{24}$

Verder kan natrekking het effect hebben dat reeds op het product gevestigde zekerheidsrechten tenietgaan. Natrekking is namelijk een vorm van originaire wijze van eigendomsverkrijging. Bij deze vorm van eigendomsverkrijging verkrijgt de verkrijger in beginsel onbezwaard. Dit betekent dat een door de producent/ verhuurder op de circulaire gevel gevestigd zekerheidsrecht tenietgaat wanneer de gevel wordt nagetrokken. ${ }^{25}$

Het bovenstaande kan de bank huiverig maken om tot financiering van een product-als-dienstmodel over te gaan. Ook voor leasemaatschappijen kan natrekking een sta in de weg zijn: een financial lease met pandrecht wordt door natrekkingsrisico een weinig aanlokkelijke propositie voor de externe financier. In het vervolg van dit artikel wordt kort ingegaan op natrekking en op de gevolgen ervan voor de bij natrekking betrokken zekerheden. Ook worden enige mogelijkheden om natrekking te voorkomen besproken. Tot slot wordt ingegaan op het gebruik van ICT-toepassingen om recht en praktijk beter op elkaar te laten aansluiten.

\section{Natrekking en zakelijke zekerheden}

\subsection{Bestanddeelvorming, natrekking en het eenheidsbeginsel}

De regels voor bestanddeelvorming liggen besloten in art. 3:4 BW. Dit artikel geeft regels voor het bepalen van de omvang van een zaak en maakt hierbij onderscheid tussen de hoofdzaak en de bestanddelen. De hoofdzaak is een zelfstandige en overdraagbare zaak en de bestanddelen zijn onderdeel van de hoofdzaak. Een bestanddeel wordt gewoonlijk niet gezien als een zaak, maar fungeert als onzelfstandig deel van de hoofdzaak.

De zelfstandigheid van een zaak gaat in beginsel verloren als deze onderdeel - lees bestanddeel - wordt van een andere zaak. Art. 3:4 BW geeft twee maatstaven voor bestanddeelvorming: een zaak kan bestanddeel worden van een andere zaak (1) op grond van de verkeersopvatting of (2) op grond van onderlinge onlosmakelijke verbondenheid. Wat als hoofdzaak wordt gezien, wordt vastgesteld met inachtneming van het bepaalde in art. 5:14 BW voor roerende zaken en het bepaalde in art. 5:20 BW voor onroerende zaken.

24 M.E. Odink \& R.H. Brandriet, Beperkte rechten en het stapelen ervan, Juridisch up to Date 2019/0056, p. 17.

25 K. Hoofs, Doorbreking van de natrekking in rechtsvergelijkend perspectief, Nijmegen: Wolf Legal Publishers 2012, p. 11-12. 
Het eigendomsrecht op de hoofdzaak omvat ook de bestanddelen van die zaak. Dit komt omdat goederenrechtelijke rechten alleen betrekking hebben op een zaak in zijn totaliteit en niet op de afzonderlijke bestanddelen van een zaak. Dit uitgangspunt wordt aangeduid als het eenheidsbeginsel en is door de Hoge Raad in het Sleepboot Egbertha-arrest voor het eerst aangenomen als leidend beginsel. ${ }^{26}$ Het eenheidsbeginsel heeft tot gevolg dat de eigenaar van de hoofdzaak, door natrekking (art. 5:3 BW) ook eigenaar wordt van zaken die bestanddeel worden van die hoofdzaak.

Het doel van het eenheidsbeginsel is om verwarring te voorkomen over de eigendomsverhoudingen van een zaak. Het aannemen van het eenheidsbeginsel wordt ook beargumenteerd met (1) het waardeargument: de som van de zaken is meer waard dan de zaken afzonderlijk en (2) het exploitatieargument: bestanddelen zijn moeilijk of niet te exploiteren. ${ }^{27}$ Een kanttekening bij het waardeargument en het exploitatieargument is dat deze argumenten gelden binnen het raamwerk van de lineaire economie. Bezien in het licht van de circulaire economie lijken deze argumenten anders gewaardeerd te moeten worden. In de circulaire economie leidt afscheiding van een zaak niet noodzakelijkerwijs tot waardeverlies. Sterker nog: het afscheiden en hergebruiken van een zaak behoort tot de kern van de circulaire economie. Hierop aansluitend, omdat een zaak - idealiter oneindig - herbruikbaar is, kan ook de exploitatiemogelijkheid van zo'n object uitstekend zijn. ${ }^{28}$ Denk in dit verband aan een modulaire smartphone die uit verschillende losse onderdelen bestaat en waarvan de modules makkelijk zijn te vervangen. De vervangen modules kunnen worden gerepareerd en weer worden gebruikt of worden gerecycled tot een grondstof voor een nieuw product. ${ }^{29}$

\subsection{Bezwaarde of onbezwaarde verkrijging?}

Bij originaire wijze van eigendomsverkrijging ontstaat het eigendomsrecht in beginsel onbezwaard. De gedachte is dat er een nieuw recht ontstaat dat niet is ontleend aan het recht van een rechtsvoorganger. Het nieuw ontstane recht kan ook niet worden beperkt door een rechtsvoorganger. Dit in tegenstelling tot de situatie bij derivatieve wijze van eigendomsverkrijging waar het recht wel van een rechtsvoorganger is afgeleid. De eigendom kan bij deze vorm van eigendomsverkrijging bezwaard overgaan. Immers, er is geen sprake van een nieuw ontstaan recht, maar van het reeds bestaande eigendomsrecht dat al dan niet bezwaard is.

27 H.D. Ploeger, Horizontale splitsing van eigendom (diss. Leiden), Deventer: Kluwer 1997, p. 34-36, 340. Voor een verhandeling over het eenheidsbeginsel in de circulaire economie zie R. Koolhoven, Worden 'slimme' zaken in de circulaire economie ook nagetrokken?, WPNR 2018/71, par. 3.2.

28 A.J. Mes, H.D. Ploeger \& B. Janssen, Eigendom van onroerende zaken, met name natrekking (titels 1 en 3), Flexibele eigendomsverhoudingen in het vastgoedrecht, in: L.C.A. Verstappen (red.), Boek 5 BW van de toekomst. Over vernieuwingen in het zakenrecht, Den Haag: Sdu 2016, p. $145-216$, p. 164. www.fairphone.com (geraadpleegd op 24 januari 2020). 
Het recht gaat over op de verkrijger in de hoedanigheid waarin het zich bevond bij de rechtsvoorganger. ${ }^{30}$

Het voorgaande brengt in beginsel met zich dat een pandrecht dat is gevestigd op een zaak, bij natrekking van deze zaak tenietgaat en de verkrijger het goed onbezwaard verkrijgt. Natrekking is immers een vorm van originaire wijze van eigendomsverkrijging. De Hoge Raad lijkt echter ruimte te zien om het onbezwaard verkrijgen te nuanceren. In het Zalco III-arrest ${ }^{31}$ relativeert hij het onbezwaard verkrijgen bij vermenging.

Deze zaak gaat over een geschil tussen drie schuldeisers van de Zeeland Aluminium Company N.V. (hierna: Zalco) te weten: pandhouder Glencore en hypotheekhouders N.V. Zeeland Seaports en N.V. Nationale Borg-Maatschappij (hierna tezamen: ZSP).

De feiten zijn als volgt. Zalco heeft een stil pandrecht gevestigd ten behoeve van Glencore op een deel van haar aluminium. Op 13 december 2011 wordt Zalco failliet verklaard. Op het moment van faillietverklaring bevatten de smeltovens van Zalco zowel het met een pandrecht bezwaard aluminium als onbezwaard aluminium. Het bezwaarde en het onbezwaarde aluminium zijn in vloeibare toestand en vermengen zich met elkaar. Kort na datum faillissement worden de smeltovens uitgezet waardoor het zich in de smeltovens bevindende aluminium stolt. Glencore meent dat zij zich op grond van het pandrecht kan verhalen op het gestolde aluminium. ZSP stellen dat het pandrecht op het gestolde aluminium teniet is gegaan. Glencore en ZSP hebben een geschil over wie recht heeft op het gestolde aluminium. De vraag die hierbij centraal staat, is of een pandrecht na vermenging van rechtswege vervalt.

Zowel de rechter in eerste aanleg als de rechter in tweede aanleg oordeelt dat het voor Glencore gevestigde pandrecht teniet is gegaan. Het hof stelt dat het verpande aluminium door vermenging met het onbezwaarde aluminium hiervan bestanddeel is geworden (art. 5:15 jo. 5:14 lid 1 en 3 BW). De Hoge Raad kiest in dit arrest voor een praktische benadering van het goederenrecht in plaats van een dogmatische benadering. De Hoge Raad stelt dat het vermengen van soortgelijke zaken niet moet leiden tot onnodig verlies van rechten en onderscheidt hierbij drie situaties:

1 Het pandrecht vervalt als het is gevestigd op een zaak die door vermenging een bestanddeel wordt van een andere zaak.

2 Het pandrecht blijft bestaan als het is gevestigd op de zaak die na vermenging wordt aangemerkt als de hoofdzaak.

3 Als er geen hoofdzaak aangewezen kan worden, dan ontstaat er ex art. 5:14 lid 2 BW een nieuwe zaak. Van rechtswege zal op (een deel van) deze nieuwe zaak een nieuw pandrecht ontstaan ten behoeve van degene die het pandrecht op de door vermenging tenietgegane zaak had gevestigd. ${ }^{32}$ 
Ook een eventueel faillissement van de schuldenaar hoeft niet in de weg te staan aan de verkrijging van het pandrecht. Het pandrecht ontstaat van rechtswege en onafhankelijk van de beschikkingsbevoegdheid van de eigenaar van het object waar het pandrecht op rust. Het fixatiebeginsel speelt derhalve geen rol. ${ }^{33}$

Gesteld dat de rechtsregel uit dit arrest ook van toepassing is bij andere vormen van bestanddeelvorming dan vermenging, dan kan de bank in geval van punt (2) en (3) een zekerheidsrecht behouden. Niettemin lijkt het twijfelachtig of de bank voordeel heeft van deze uitgangspunten. De bank zou bij natrekkingsvraagstukken een zekerheidsrecht behouden als de zaak waar het zekerheidsrecht op rust als hoofdzaak wordt aangewezen of als er geen hoofdzaak kan worden vastgesteld. Bij circulaire product-als-dienstmodellen zal de te verhuren zaak dikwijls niet worden aangemerkt als hoofdzaak, maar als bestanddeel van een andere hoofdzaak. Bijvoorbeeld in het geval van geïntegreerde zonnepanelen of bij een warmte- en koudeopslagsysteem. ${ }^{34}$

\subsection{Het voorkomen van natrekking}

Het opstalrecht (art. 5:101 BW) wordt in de praktijk gebruikt om natrekking in de zin van art. 5:20 BW te voorkomen. De opstaller wordt door het recht van opstal bevestigd in zijn volledige eigendomsrecht van de opstal. ${ }^{35}$ Het opstalrecht heeft blijkens art. 5:101 lid 2 BW twee vormen: (1) als zelfstandig recht op een onroerende zaak en (2) als afhankelijk recht van een ander gebruiksrecht op een onroerende zaak. Het is mogelijk om een hypotheekrecht te vestigen op een zelfstandig opstalrecht. Hierbij vallen de opstallen via het opstalrecht ook onder het hypotheekrecht. Een afhankelijk opstalrecht kan niet verhypothekeerd worden. Uit een objectieve uitleg ${ }^{36}$ van de vestigingsakte moet blijken of een opstalrecht zelfstandig of afhankelijk is. ${ }^{37}$

Het opstalrecht richt zich op het afsplitsen van 'gebouwen en werken' van een andere onroerende zaak. Dit betekent dat deze 'gebouwen en werken' zelf al in zekere mate zelfstandig dienen te zijn. Wanneer een object voldoende zelfstandig is om vatbaar te zijn voor het recht van opstal is niet altijd duidelijk. ${ }^{38}$ Ook is er in de literatuur discussie over de vraag of het opstalrecht kan worden gebruikt om een object te verzelfstandigen dat naar verkeersopvatting onderdeel is van een bouwwerk. ${ }^{39}$ Auteurs die deze vraag positief beantwoorden doen dit onder de

34 E.F. Verheul \& F.M.J. Verstijlen, Een pleidooi voor meer continuïteit in het goederenrecht, in: L.C.A. Verstappen (red.), Boek 5 van de toekomst. Over vernieuwingen in het zakenrecht, Den Haag: Sdu 2016, p. 65-144, p. 133-134.

35 Asser/Bartels \& Van Velten 5 2017/243; GS Zakelijke rechten, titel 8 Boek 5 BW, aant. A.

36 HR 8 december 2000, NJ 2001/350 (Eelder Woningbouw/Van Kammen); HR 22 oktober 2010, NJ 2011/111 (Kamsteeg/Lisser).

37 Asser/Bartels \& Van Velten 5 2017/250, 255

38 B. Legger, De circulaire economie en het product als dienst-model in het Nederlandse goederenrecht, Tijdschrift voor Zakenrecht 2018, nr. 3-4, p. 29-31, p. 30.

39 Ploeger 1997, p. 214; F.J. Vonck, De flexibiliteit van het recht van erfpacht (diss. Groningen), Den Haag: Boom Juridische uitgevers 2013, p. 61; P.J. van der Plank, Natrekking door onroerende zaken (diss. Nijmegen), Deventer: Wolters Kluwer 2016, p. 50-51; Asser/Bartels \& Van Velten 5 2017/248c. 
voorwaarden dat het object voldoende economische zelfstandigheid heeft en kwalificeert als werk ex art. 5:101 BW. ${ }^{40}$ Deze auteurs mogen zich ogenschijnlijk gesteund voelen door de Hoge Raad. Uit zijn transformatorarresten ${ }^{41}$ lijkt te volgen dat 'art. 3:4-bestanddelen' door een opstalrecht kunnen worden verzelfstandigd. ${ }^{42}$ Hoe dan ook, de gedachten over dit leerstuk zullen zich de komende jaren onder druk van een veranderende economische realiteit ongetwijfeld scherpen.

In de praktijk wordt ook gebruikgemaakt van het recht van erfpacht (art. 5:85 e.v. BW) om de gevolgen van natrekking te mitigeren, ${ }^{43}$ bijvoorbeeld bij een circulaire gevel. ${ }^{44}$ Hoewel natrekking van de gevel met het erfpachtrecht niet wordt voorkomen, kan de economische eigendom ervan worden vastgelegd in de erfpachtovereenkomst. Partijen kunnen in de erfpachtovereenkomst afspraken maken over financiële rechten en plichten, maar ook over het onderhoud en de verwijdering van de zaak in kwestie. ${ }^{45}$ Zeker over dit laatste punt zullen partijen nadere afspraken moeten maken. Het wettelijk wegnemingsrecht ex art. 5:89 lid 3 BW geldt alleen voor gebouwen en werken die de erfpachter onverplicht heeft aangebracht. Omdat de erfpachter (de producent/verhuurder) op grond van zijn contractuele verplichting jegens de gebruiker ertoe is gehouden om zijn werk (in het voorbeeld: de circulaire gevel) aan te brengen, heeft hij de jure niet de mogelijkheid om deze objecten terug te nemen. Wel heeft hij aan het einde van de erfpacht krachtens art. 5:99 BW recht op een vergoeding voor de aangebrachte werken, maar dit is niet in lijn met de circulaire gedachte: het goed komt immers niet terug bij de producent/verhuurder en derhalve ontbreekt de stimulans om zo veel mogelijk waarde aan het goed toe te voegen. Sterker nog, nadat het werk is aangebracht heeft de producent/verhuurder geen economisch reden (eventuele contractuele verplichtingen daargelaten) om het te onderhouden. De producent/verhuurder krijgt met de vergoeding in de zin van art. 5:99 BW hoe dan ook zijn geld. Dit mechanisme bevordert ook niet dat het ontwerp van het betreffende goed duurzaam is en gericht is op hergebruik. In de literatuur wordt er daarom voor gepleit dat de erfpachter een ruimer wegnemingsrecht toekomt. ${ }^{46}$

Indien partijen afspraken maken over een ruimer wegnemingsrecht, dan rijst de vraag of partijafspraken in de akte van vestiging vorm kunnen geven aan de inhoud van het erfpachtrecht. In de Toelichting Meijers bij art. 5:89 BW lijkt dit

40 Asser/Bartels \& Van Velten 5 2017/248c; GS Zakelijke rechten, art. 5:101 BW, aant. 1.9.

41 HR 5 januari 2018, ECLI:NL:HR:2018:12, ECLI:NL:PHR:2017:1205, JOR 2018/115, m.nt. Bartels.

42 S.E. Bartels, annotatie bij HR 5 januari 2018, ECLI:NL:HR:2018:12, ECLI:NL:PHR:2017:1205, JOR 2018/115, nr. 5; E.E. van der Kamp, annotatie bij HR 5 januari 2018, ECLI:NL:HR:2018:12, ECLI:NL:PHR:2017:1205, JIN 2018/35, nr. 9, 10.

43 Ook de kwalitatieve verplichting en het appartementsrecht worden gebruikt. P.J. van der Plank \& D. de Jong, Instrumenteel gebruik van het recht van erfpacht in het kader van circulair bouwen, WPNR 7224, p. 64-70.

44 Houthoff, Circulaire toepassing van het Erfpachtrecht, digitaal te raadplegen op: www.houthoff.com/-/media/Houthoff/Publications/maarts/HF_Circulaire-toepassing-van-hetErfpachtrecht_3p_DEF.pdf, (geraadpleegd op 4 februari 2020).

45 GS Zakelijke rechten, art. 5:20 BW, aant. 1.6.4.

46 Legger 2018, p. 31. 
niet te zijn uitgesloten. ${ }^{47}$ Beantwoording van deze vraag is bepalend voor de vraag of aan deze afspraken goederenrechtelijke werking toekomt. Niettemin beperkt de goederenrechtelijke aard van de rechtsverhouding tussen partijen hun vrijheid om de inhoud van de erfpacht vorm te geven. Partijafspraken moeten zich verhouden tot enerzijds het erfpachtrecht en anderzijds het goederenrechtelijk systeem. Afspraken tussen de erfverpachter en de erfpachter worden alleen gezien als onderdeel van het recht van erfpacht als deze afspraken zijn opgenomen in de akte van vestiging en voldoende verband houden met het wezen van de erfpacht. Contractuele verplichtingen tot een dulden kunnen onderdeel uitmaken van de goederenrechtelijke verhouding. Dit is anders bij doe-verplichtingen. In de literatuur bestaat er debat over de mate waarin partijafspraken over doe-verplichtingen die niet voortvloeien uit de wet, onderdeel zijn van de goederenrechtelijke verhouding. ${ }^{48}$ Struycken bijvoorbeeld meent dat deze positieve verplichtingen in beginsel geen onderdeel zijn van de goederenrechtelijke verhouding. Deze doeverplichtingen zouden mogelijk te belastend zijn voor rechtsopvolgers onder bijzondere titel die doorgaans geen partij zijn geweest bij het overeenkomen ervan. ${ }^{49}$ Niettemin ziet Struycken wel ruimte voor relativering. Het is volgens hem denkbaar dat wordt afgeweken van het bovenstaande wanneer de aanvullende bevoegdheid of verplichting voortkomt uit maatschappelijke gebruiken bij een specifiek goederenrechtelijk recht. ${ }^{50}$ De opvatting van Struycken zorgt voor een zekere flexibiliteit om recht en de veranderende praktijk beter op elkaar te laten aansluiten. Een dergelijke flexibiliteit zou de ontwikkeling van de circulaire economie kunnen helpen. Met betrekking tot het verruimde wegnemingsrecht van de erfpachter (producent/verhuurder van de circulaire gevel) is het verdedigbaar dat het gaat om een verplichting van de erfverpachter (klant/huurder) tot een dulden - van het wegnemen van de circulaire gevel - die ook voldoende verband houdt met het wezen van het erfpachtrecht, zodat kan worden betoogd dat het verruimde wegnemingsrecht tot de inhoud behoort van het erfpachtrecht.

Indien het verruimde wegnemingsrecht onvoldoende verband zou houden met het wezen van de erfpacht, dan werkt deze afspraak alleen tussen de erfverpachter en de erfpachter. De afspraak gaat in dit geval bij vervreemding van het erfpachtrecht door de producent/verhuurder of de bloot-eigendom door de klant/ huurder niet van rechtswege over op een toekomstige verkrijger onder bijzondere titel. ${ }^{51}$ Dit is mogelijk anders wanneer het wegnemingsrecht van de producent/ verhuurder met betrekking tot de circulaire gevel wordt vormgegeven als een kwalitatieve verplichting van de klant/huurder zoals bedoeld in art. 6:252 lid 1 BW. Deze bepaling biedt de mogelijkheid om bij overeenkomst af te spreken dat een verplichting tot een dulden of een niet-doen betreffende een registergoed, overgaat op rechtsopvolgers onder bijzondere titel en dat mede gebonden zijn partijen die van de rechthebbende een recht tot gebruik verkrijgen. De overeen-

47 Parl. Gesch. Boek 5, p. 308.

48 Zie Vonck 2013, p. 135 e.v. voor een uiteenzetting van de verschillende posities in dit debat.

49 Struycken 2007, p. 428. Anders Rank-Berenschot, Goederenrecht 2012/664; Asser/Bartels \& Van Mierlo 3-IV 2013/47 en 48.

50 Struycken 2007, p. 429.

51 Asser/Bartels \& Van Velten 5 2017/217. 
komst moet krachtens art. 6:252 lid 2 BW worden neergelegd in een notariële akte, gevolgd door inschrijving daarvan in de openbare registers.

Een voorwaarde om het wegneemrecht vorm te kunnen geven als een kwalitatieve verplichting is dat het wegneemrecht wordt gekwalificeerd als een verplichting tot dulden. Zoals vermeld, gezien vanuit het perspectief van de erfverpachter (de klant/huurder) kan het wegnemingsrecht als zodanig worden beschouwd. Hij heeft te dulden dat de producent/verhuurder de circulaire gevel weer van het gebouw verwijdert. Het vormgeven van het wegnemingsrecht als een kwalitatieve verplichting lijkt daarom niet te worden belemmerd op grond van deze voorwaarde. Echter, met het op deze wijze vormgeven van het wegneemrecht heeft de bank nog geen zekerheid verkregen. Mocht de producent/verhuurder deze zekerheid willen bieden door het erfpachtrecht aan de bank te verhypothekeren, dan is het voor de bank belangrijk dat het (verruimde) wegneemrecht onderdeel is van het erfpachtrecht. Als bij executie de executiekoper van het erfpachtrecht namelijk ook het verruimde wegneemrecht verkrijgt, dan heeft dit mogelijk een positief effect op de executiewaarde. ${ }^{52}$

Wanneer het (verruimde) wegneemrecht niet wordt gerekend tot het erfpachtrecht, dan kan de bank mogelijk zekerheid ontlenen aan dit wegneemrecht als het kan worden gekwalificeerd als een kwalitatief recht (art. 6:251 BW). De redenering is dan dat de erfpachter (de producent/verhuurder) alleen belang heeft bij het (verruimde) wegneemrecht, dat correspondeert met de kwalitatieve verplichting van de klant/huurder (bloot-eigenaar/erfverpachter), zolang hij erfpachter is, zodat het wegneemrecht kan worden gezien als een kwalitatief recht verbonden aan de hoedanigheid van erfpachter. Bij vervreemding van het erfpachtrecht gaat in dit geval ook het verruimde wegneemrecht over op de verkrijger van het erfpachtrecht. Dit geldt ook als de bank van de producent/verhuurder als hypotheekhouder van het erfpachtrecht het erfpachtrecht executoriaal verkoopt.

In het kader van het bieden van zekerheden zou de vraag op kunnen komen of het (verruimde) wegneemrecht ook aan de bank kan worden verpand. Om vatbaar te zijn voor verpanding moet het wegneemrecht worden aangemerkt als een voor overdracht vatbaar goed (art. 3:228 jo. 3:83 lid 1 BW). Hoewel het (verruimde) wegneemrecht kan worden gezien als een vorderingsrecht, is het de vraag of dit wegneemrecht separaat van het erfpachtrecht overdraagbaar is. Dit is mogelijk twijfelachtig omdat het (verruimde) wegneemrecht, gezien als kwalitatief recht, in zodanig verband staat met het goed (het erfpachtrecht) dat alleen de erfpachter hier belang bij heeft. Verpanding is dan wellicht niet mogelijk. Daarnaast is het de vraag of een vorderingsrecht tot een dulden kan worden 'geïnd' door een pandhouder in de zin van art. 3:246 lid 1 BW. Tegelijkertijd zou ook kunnen worden betoogd dat de hypotheekhouder van het erfpachtrecht een duidelijk

52 Overigens is het de vraag of de bank als hypotheekhouder het wegneemrecht kan uitoefenen en of constructies hiertoe de lakmoesproef van het faillissement doorstaan. Zie eveneens noot 53. 
belang heeft bij het (verruimde) wegneemrecht en dat daarom verpanding van dit recht aan hem mogelijk zou moeten zijn. ${ }^{53}$

Het wegneemrecht zou naast dat het kan worden vormgegeven als een kwalitatieve verplichting, ook kunnen worden vormgegeven met behulp van art. 7:216 BW. Dit artikel gaat over het wegneemrecht dat een huurder toekomt inzake de door hem aangebrachte veranderingen en toevoegingen aan het gehuurde. De huurder kan tot de ontruiming deze veranderingen en toevoegingen ongedaan maken. Hierbij dient de huurder het gehuurde in de toestand te brengen die bij het einde van de huur redelijkerwijs in overeenstemming met de oorspronkelijke toestand kan worden geacht. Deze regeling gaat ook op ingeval de betreffende veranderingen of toevoegingen bestanddeel zijn geworden van het gehuurde en hierdoor onder het eigendomsrecht vallen van de verhuurder. Het wegneemrecht geeft de huurder de mogelijkheid om dergelijke toevoegingen ongedaan te maken en te onttrekken aan het eigendom van de verhuurder. ${ }^{54}$

Op grond van het voorgaande kan als volgt tot een wegneemrecht worden gekomen voor de producent/verhuurder van een circulaire gevel. De gedachte is dat de producent/verhuurder dat deel van het gebouw huurt waar de toevoeging, de circulaire gevel, aan wordt bevestigd. Vervolgens wordt een huurtermijn voor dat deel van het gebouw afgesproken die iets langer doorloopt dan de huurtermijn van de toevoeging. Bij afloop van de huurtermijn van de toevoeging kan de producent/verhuurder de toevoeging vervolgens wegenemen. Deze juridische constructie kan mogelijk ook de bank tot (indirect) voordeel strekken, al was het maar omdat de producent/verhuurder meer zekerheid verkrijgt over het terugkrijgen van het verhuurde. Wanneer het mogelijk zou zijn om het wegneemrecht ex art. 7:216 BW te verpanden aan de bank (vergelijk hiervoor), dan zou de bank ook op een meer directe wijze zekerheid aan dit recht kunnen ontlenen. ${ }^{55}$ In het bijzonder omdat bij faillissement van de huurder (de producent/verhuurder) het wegneemrecht kan worden uitgeoefend. Tegelijkertijd wordt het wegneemrecht ook niet aangetast door een faillissement van de verhuurder (de klant/huurder). De curator is gehouden om een dergelijke verplichting tot een dulden te respecteren. ${ }^{56}$

53 Opgemerkt wordt dat de zekerheid voor de bank alleen effectief is als zij verhaal kan nemen op het verwijderde werk. In dit licht zijn de nodige vraagtekens te plaatsen bij de effectiviteit van een pandrecht op het (verruimde) wegneemrecht van de erfpachter (producent/verhuurder). Het is allerminst duidelijk of aanvullende constructies die beogen te bewerkstelligen dat de bank zich kan verhalen op het verwijderde werk faillissementsbestendig zijn. Zoals de constructie waarbij de producent/verhuurder aan de bank het in de toekomst te verwijderen werk bij voorbaat verpandt.

54 Asser/Rossel \& Heisterkamp 7-II 2017/138.

55 Niettemin gelden er bij het verpanden door de huurder van zijn wegneemrecht ex art. 7:216 BW dezelfde aandachtspunten als bij de verpanding van het (verruimde) wegneemrecht van de erfpachter.

56 Asser/Rossel \& Heisterkamp 7-II 2017/140. Zie ook HR 11 juli 2014, ECLI:NL:HR:2014:1681, NJ 2014/407 (Berzona), r.o. 3.6.4. 


\subsection{ICT en de inpasbaarheid van de praktijk in het recht}

Om recht en praktijk (beter) op elkaar te laten aansluiten, willen de literatuur en de praktijk nog wel eens hun toevlucht nemen tot ICT-toepassingen. ${ }^{57} \mathrm{Zo}$ is het ook bij natrekking indachtig het product-als-dienstmodel. Een voorbeeld hiervan is het 'Façade Identification System' (FIS). Dit systeem individualiseert afzonderlijke gevelelementen, waardoor het bijvoorbeeld mogelijk wordt om via het vestigen van een recht van erfpacht op de grond en het gebouw, het gebruiksrecht toe te spitsen op de afzonderlijke gevelelementen. ${ }^{58}$

Het nauwkeurig registeren van de afzonderlijke objecten van een bouwwerk lijkt een opening te bieden om deze objecten rijp te maken voor toepassing van zakelijke rechten. Hieraan kan ook een bouwinformatiemodel (BIM) bijdragen. Een dergelijk model is een database van een bouwwerk waarmee betrokken partijen van ontwerp tot sloop onderling relevante data uitwisselen. De database vormt een driedimensionale digitale maquette van een bouwwerk waarin allerhande informatie is gekoppeld aan objecten. ${ }^{59}$

Ook een register als Madaster kan ter zake een bijdrage leveren. Het doel van het Madaster is om '(...) afval te elimineren door materialen een identiteit te geven' ${ }^{6}$ In dit register worden gegevens over gebouwen en materialen bewaard. Er wordt een zogenoemd materialenpaspoort gemaakt. Uit dit paspoort blijkt welke materialen in een gebouw zijn verwerkt. Hierbij worden ook de kwaliteit van de materialen en de financiële en circulaire waarde geregistreerd.

ICT-toepassingen in combinatie met bijvoorbeeld een opstalrecht zou natrekking mogelijk kunnen voorkomen. Zodoende wordt vermeden dat eventuele gevestigde zekerheden tenietgaan. Ook wanneer natrekking niet kan worden voorkomen, kunnen ICT-toepassingen de bank en de producent/verhuurder een vorm van zekerheid bieden. In de literatuur is erop gewezen dat als de digitale infrastructuur van een zaak dusdanig is dat een zaak op afstand kan worden uitgeschakeld of bij afwezigheid van updates niet meer bruikbaar is, dit kan fungeren als een de facto zekerheidsrecht voor de producent/verhuurder. Het vergroot namelijk de kans dat de huur wordt betaald. Immers, de klant/huurder die door natrekking eigenaar is geworden van een 'slimme zaak', of meent dat hij dit is geworden, zal of doorgaan met het betalen van huurpenningen om de werking van de slimme zaak te garanderen, of de producent/verhuurder (of diens bank) de gelegenheid geven de slimme zaak op te halen. ${ }^{61}$ Niettemin biedt dit de facto zekerheidsrecht de bank geen echte zekerheid. Bij faillissement van de producent/ verhuurder zullen de na datum faillissement vervallen huurtermijnen in de boedel vallen (art. 35 lid 2 Fw). Ook als de curator een 'slimme zaak' krijgt geretourneerd, komt deze zaak toe aan de boedel en niet aan de bank. Hierbij is het niet mogelijk dat een aan de bank bij voorbaat verleend pandrecht op de zaak de boedel wordt tegengeworpen.

57 Mes, Ploeger \& Janssen 2016, p. 175.

58 Vereniging van Metalen Ramen en Gevelbranche (VMRG), Façades, 2018, p. 7 e.v.

59 R. Sebastian e.a., Blauwdruk voor (juridische) afspraken voor samenwerking in projecten met BIM, Rapport TNO 2013 R10877/1, 1 juli 2013, p. 6 e.v.

60 www.madaster.com/nl/over-ons/visie-missie-doelstelling, geraadpleegd op 13 juni 2019.

61 Koolhoven 2018, par. 6. 
Verder kunnen de natrekkingsregels ertoe leiden dat er meer vermogensbestanddelen vallen onder het hypotheekrecht van de bank van de klant/huurder. Of de bank vervolgens profijt heeft van deze vermogensbestanddelen is gezien het voorgaande niet zonder meer duidelijk. Het zou goed kunnen dat het hypotheekrecht zich feitelijk over minder vermogensbestanddelen uitstrekt dan juridisch aanvankelijk gedacht.

ICT kan ervoor zorgen dat het vigerend recht beter aansluit op de circulaire economie zonder dat grondslagen van het (zakelijk) recht moeten worden aangepast. Niettemin zijn er auteurs met voorstellen voor een lex ferenda inzake bestanddeelvorming en natrekking. Bijvoorbeeld: aanpassing van de verkeersopvatting in de zin van art. 3:4 lid 1 BW. De gedachte is dat de verkeersopvatting een zeker adaptief vermogen heeft om zich aan te passen aan veranderende gewoonten in de praktijk. In de parlementaire geschiedenis bij art. 3:4 lid 1 BW wordt de mogelijkheid uitdrukkelijk genoemd:

'(...) dat zich een gewoonte ontwikkelt enerzijds om kostbare roerende zaken die bestemd zijn in samenhang met een onroerende zaak te worden gebruikt, aldus te construeren en de verbinding daarvan met deze onroerende zaak aldus in te richten, dat opheffing van deze verbinding zonder bezwaar kan geschieden, en anderzijds om overeen te komen dat de eigendom van deze roerende zaken zal blijven waar zij is. Aldus zal zich in de praktijk een verkeersopvatting kunnen vormen die aan een beding van eigendomsvoorbehoud werking toekent, juist in die gevallen dat afscheiding als economisch niet onwenselijk en als een reëel belang van de maker van het beding kan worden beschouwd. ${ }^{62}$

Ook in de rechtspraak zijn er voorbeelden waarbij de verkeersopvatting zodanig wordt geïnterpreteerd dat bestanddeelvorming van het verhuurde product uitblijft. In het De Zaanlandse III-arrest ${ }^{63}$ gebruikt de Hoge Raad de verkeersopvatting om uitsluitsel te geven of apparatuur dat onder eigendomsvoorbehoud in een schip is aangebracht, kwalificeert als scheepsbestanddeel of als scheepstoebehoren. Als de apparatuur als scheepsbestanddeel wordt aangemerkt dan heeft dit het gevolg dat het eigendomsvoorbehoud wordt doorbroken en de eigenaar van het schip ook eigenaar wordt van de apparatuur. De Hoge Raad oordeelt dat de betreffende apparatuur volgens de verkeersopvatting scheepstoebehoren is, en daarom geen deel uitmaakt van het schip, als het contractueel gangbaar is dat deze apparatuur slechts aan de eigenaar van het schip in huur wordt gegeven terwijl de verhuurder zorg blijft dragen voor het onderhoud ervan.

Gezien het voorgaande is het geenszins onmogelijk dat na verloop van tijd een verkeersopvatting ontstaat waarbij, in een specifieke situatie, een door circulaire ondernemingen verhuurd product niet wordt gezien als een bestanddeel van een andere zaak. Natrekking door bestanddeelvorming blijft bijgevolg achterwege. Van belang is hierbij of partijafspraken die beogen om de eigendom van een ver- 
huurde zaak voor de verhuurder te behouden, door de branche als gebruikelijk worden gezien. Dit laat wellicht ruimte voor brancheorganisaties om sturing te geven aan de ontwikkeling van de verkeersopvatting bij bestanddeelvorming door ter zake brancheafspraken te maken en om deze afspraken te verwerken in modelovereenkomsten.

Ook zijn er auteurs die een lezing van het eenheidsbeginsel voorstaan die meer is toegesneden op de circulaire economie. De gedachte van deze auteurs is dat het eenheidsbeginsel wordt onderbouwd met argumenten die gelden in de lineaire economie, maar niet in de circulaire economie. Zoals in paragraaf 4.1 is opgemerkt heeft het waardeargument (de som van de zaken is meer waard dan de (afgescheiden) zaken afzonderlijk) minder overtuigingskracht wanneer dit argument wordt gewaardeerd in de context van de circulaire economie. In de circulaire economie staat het afscheiden en hergebruiken van een zaak centraal. Daarom leidt het afscheiden van een zaak niet onvermijdbaar tot waardeverlies. Gelezen dit voorgaande stellen auteurs dat er in titel 3 Boek 5 BW meer ruimte moet worden geboden aan de partijautonomie om de ontwikkeling van de circulaire economie te bevorderen. Auteurs wijzen in dit verband ook op het gebruik van ICT-oplossingen om de kenbaarheid van het doorbreken van de natrekking te waarborgen, bijvoorbeeld door toepassing van het eerder besproken bouwinformatiemodel. Auteurs pleiten in dit licht eveneens voor een openbaar register in lijn met het niet ingevoerde derde lid van het Ontwerp Meijers art. 3.1.1.3 (thans art. 3:4 BW). Dit derde lid ziet op het doorbreken van de natrekking als een eigendomsvoorbehoud van de verkoper is ingeschreven in de openbare registers. Hierbij wordt opgemerkt dat indachtig het voorgaande aanpassing van titel 3 Boek 5 BW niet beperkt moet worden tot een regeling die alleen gaat over de levering onder eigendomsvoorbehoud, maar gericht moet zijn op in de circulaire economie gangbare eigendomsverhoudingen. ${ }^{64}$

\section{Slotbevindingen}

Een kredietaanvraag voor een circulaire propositie wordt door de bank beoordeeld met een risico-inschatting. De risico-inschatting kan een vertroebeld beeld geven wanneer waarden worden gebuikt die gelding hebben in de lineaire economie. De bank zal om een adequate risico-inschatting van een circulaire propositie te kunnen maken, het betreffende circulaire verdienmodel uitgebreid moeten analyseren. Maatwerk is het devies. De bank moet inzicht krijgen in de waardeketen waarin de krediet vragende onderneming zich bevindt. Verder dient de bank een goed beeld te hebben van de 'circulaire waarde' van het product. Het voorgaande geldt ook bij het product-als-dienstmodel. Hierbij moet de bank rekening houden met de kredietwaardigheid van de klant/huurders, eventuele risico's die voortvloeien uit de duurovereenkomst en de bank moet bedacht zijn op natrekkingsrisico. Dit is des te belangrijker wanneer de bank een kredietaanvraag krijgt 
van een onderneming die het product-als-dienstmodel toepast op producten van geringe waarde, beperkte courantheid of die vatbaar zijn voor natrekking.

Natrekking kan ertoe leiden dat zekerheden niet gevestigd kunnen worden of als gevolg van natrekking tenietgaan. Natrekking in geval van art. 5:20 BW kan worden doorbroken door een opstalrecht. Echter, het opstalrecht biedt niet in alle gevallen soelaas. Soms kan een toevlucht worden gezocht tot het erfpachtrecht, maar ook dit recht kent zijn beperkingen. De mate waarin deze rechten effectief zijn, hangt vaak samen met de mate waarin een object zelfstandig genoeg is om vatbaar te zijn voor een zakelijk recht. Hierover bestaat discussie in de literatuur. Met ICT-toepassingen wordt geprobeerd de praktijk inpasbaar te houden in het recht. Dit betekent niet dat het vigerende recht niet ter discussie wordt gesteld: het tegendeel is waar. Naarmate de circulaire economie aan terrein wint, lijkt het onvermijdelijk dat bestaande opvattingen over het geldend recht aangaande bestanddeelvorming en natrekking in toenemende mate ter discussie komen te staan. 